\title{
AN EMPIRICAL BIOTIC INDEX OF THE QUALITY OF WATER IN SOUTH AFRICAN STREAMS AND RIVERS
}

\author{
F. M. ChutTer \\ Natal Regional Laboratory, National Institute for Water Research, \\ South African Council for Scientific and Industrial Research, \\ P.O. Box 1, Congella, Natal, South Africa
}

(First received 27 July 1970 and in final form 16 August 1971)

\begin{abstract}
A method of reducing data on stones-in-current faunal communities to a linear scale of water quality in terms of organic pollution is presented. Using data from extensive river surveys each taxon has been allotted a Quality Value (between 0 and 10) related to its occurrence in variously polluted waters. To arrive at the Biotic Index Value of a community, a faunal sample is taken and the individual animals are recorded by taxa. The number of individuals of each taxon is then multiplied by the taxon's Quality Value. The products of these multiplications are summed for the sample and this sum is then divided by the total number of individuals in the whole sample to give the Biotic Index Value.

Quality Values for taxa occurring in large numbers in a wide range of water qualities vary according to the diversity and abundance of the Baetid Ephemeroptera. It is not necessary to identify all animals to the species level and sample size is not critically important. The Biotic Index is compared with indices due to other authors.
\end{abstract}

\section{INTRODUCTION}

THE LITERATURE on the biological assessment of water pollution up to 1959 has been reviewed by HYNES (1960) and by HAWKEs (1962). Both authors agree on the limited usefulness of the Saprobiensystem (KolKwITZ and MARSSON, 1908, 1909; KolKwITZ, 1950) and its later modification (LIEBMANN, 1951), because of its rigidity and because all indicator organisms, including those associated with the most severely polluted waters, occur in natural waters. Moreover the Saprobiensystem is, as Hynes says, "applicable only to the particular conditions produced by heavy sewage pollution in a slow and evenly flowing river". However the contribution of biological studies to the assessment of water quality is greatest in conditions of toxic, of intermittent and of slight or mild organic pollution, where changed water quality is not readily detected by chemical means. Both Hynes and Hawkes refer to the systems for the biological classification of water quality due to PATRICK $(1950,1951)$ and WURTZ (1955). Neither of these is really satisfactory as they result in findings which cannot be expressed simply and in an easily understandable fashion. Hynes concluded that because the pattern of pollution varies from place to place the most appropriate way of showing the biological effects of pollution is to give comparative numerical data in Tables. Hawkes was more prepared to argue the desirability of a biological index of water quality, a need emphasized by the number of indices which have appeared since 1962. The need for biological indices is well explained by WooDiwiss (1964).

BEAK (1965) studied the macroinvertebrates living in and on the silty bottom of a large Canadian river. From data gathered over a $6 \mathrm{yr}$ period he derived a biotic index of water quality which was based on the feeding habits, sensitivity to pollution and density of the macroinvertebrates. The index has inherent weaknesses in that the feeding habits of many species are unknown, the sensitivity to pollution of animals is a 
matter of opinion and the experience of the investigator and the assessment of density is also subjective-terms such as "reduced in population density", "fairly large numbers", "large numbers" and "excessively large numbers" being used. However Beak's index is an advance over the original Saprobiensystem in that the whole macroinvertebrate fauna and not only indicator species is used and an attempt is made to make use of the numbers of individuals of the various species encountered.

An altogether different approach to the biological assessment of stream conditions was adopted by Woodrwiss (1964). He devised a scheme in which the number of groups of macroinvertebrates (groups consisting of defined taxa) was related to the presence of six key organisms (or groups of organisms), which were Plecoptera, Ephemeroptera, Trichoptera, Gammarus, Asellus and Tubificids/red Chironomid larvae. Depending on the number of groups present and the key organisms in the fauna, biological index values range from 10 (clean water fauna) to 0 (very polluted water fauna). While Woodiwiss's system is probably highly successful in the area for which it was designed, it is not easily applicable to South African streams and rivers because no less than three of the key groups are absent (Gammarus, Asellus) or of very restricted occurrence (Plecoptera) in fresh waters in southern Africa. The advantages of Woodiwiss's system are that index values fall within a defined range and that sample sorting time is reduced because there is no counting of individuals in samples.

More recently attempts have been made to use measures of diversity in the biological assessment of pollution (WILHM, 1967, 1970; CAIRNS et al., 1968). The use of diversity indices is based on the fundamental concept (due to BUTCHER, 1946) that organic pollution tends to restrict the variety of organisms, with a simultaneous increase in the density of those forms capable of tolerating the changed conditions. Wilhm has used diversity parameters derived from information theory, parameters whose derivation is described in more detail by PATTEN (1962). Practical shortcomings of the information theory diversity indices are that the calculations are so intricate that they have to be computed using a computer and the interpretation of the values obtained is not straightforward, because the limits within which values may fall are not clearly defined. The parameters are influenced by sample size, a difficulty which may be overcome by taking large samples (PIELOU, 1966; WILHM, 1970). The diversity index suggested by CAIRNS et al., a sequential comparison index, involves simple calculations, and has further advantage that the resulting index values must lie within known limits $(0$ and 1$)$. The index is based on a defined number of organisms taken at random from a sample, so that the index value is not affected by sample size. In practice the handling of macroinvertebrate samples for the application of the sequential comparison index presents certain difficulties. It is not easy to obtain a random distribution of the collected animals (whose size and weight is variable) in a container in which they may be examined under a binocular microscope. Personal experience with preserved Simuliid larval collections, in which the larvae ranged in size from first to final instar, was that the currents generated when pouring the water-suspended larvae into a $7 \times 7 \mathrm{~cm}$ dish were sufficient to result in a non-random distribution of the various sized larvae.

Biological indices based on diversity indices do not require that the organisms found be taxonomically identified and it has been claimed that they may therefore be used by investigators with limited taxonomic background (CAIRNS et al., 1968; MATHIS and DORRIS, 1968; WILHM and DoRRIS, 1966). Appealing as the apparent economy in 
trained manpower may be, the author doubts that the claim is really justified. It would only be justified when the taxa to be considered different from one another were clearly defined for the investigators and the investigators had sufficient biological acumen to apply the defined taxonomic classification consistently. Moreover, to rely on diversity index values for the biological assessment of water quality is sometimes extremely wasteful of readily available and obvious information revealed by the kind of animals present. To take an extreme case it would be inane to ignore the obvious conclusion to be drawn from a stones-in-current faunal sample which consisted mainly of Tubificidae and Chironomus larvae, for the sake of not having to know what a Tubificid or a Chironomus larvae look like.

HARRISON (1961) emphasized the need for widespread and detailed studies of the occurrence of the South African freshwater macroinvertebrate fauna, to provide information on existing conditions in streams and rivers against which future conditions might be compared. Moreover as the variation of the fauna in relation to water quality came to be known, the fauna would provide a useful measure of water quality. Now that the macroinvertebrate fauna of many South African rivers is known (HARRISON and ElswORTH, 1958; HARRISON, 1958a, 1958b; OlifF, 1960a, 1960b, 1963; AllaNSON, 1961 ; ChUTTER, 1963, 1968, 1970, 1971) an attempt has been made to construct a faunal index of stream and river quality which is presented here. The measure has been called a Biotic Index and is described in the knowledge that it will not be exactly applicable outside southern Africa. However it is hoped that the manner, in which certain taxonomically difficult groups of animals (Oligochaeta, Chironomidae) have been treated, will be useful to workers in other parts of the world.

\section{DEFINITION AND LIMITATIONS OF THE BIOTIC INDEX}

The Biotic Index developed here is a measure of the pollution of flowing water by allochthonous readily oxidizable organic matter and its breakdown products. It is based on three hypotheses concerning the fauna. They are that the faunal communities of clean streams and rivers are definable, that they change in a predictable way as organic matter is added to the water and that the greater the amount of oxidizable organic matter added, the greater will be the change in the fauna. The Biotic Index summarizes the deviation of the observed community of animals from the community which would be expected were the water in an unenriched natural state.

This type of index of water quality has a number of limitations. Aquatic biocoenoses are not only influenced by organic pollution, but also by poisons such as pesticides, heavy metals and phenols. These may impair water quality and kill some, but not necessarily all, stream animals. Since the Biotic Index is based on all the animals present, poisons are liable to result in misleading Biotic Index values. Other limitations of the Biotic Index come about because faunal variability is related to several factors in addition to water quality. In South Africa the most important of this category of disrupting factors is a considerable instability of flows and river beds in the rainy season.

It is therefore desirable to consider the fauna with these limitations in mind, before attempting to apply a Biotic Index related to organic pollution. Today there is some knowledge of the effect of several types of poison on stream invertebrates (HYNES, 1964). Broadly speaking Hynes reported that insecticides kill insects and crustacea but 
not worms and snails, while metals eliminate snails and worms and leave insects. As a rule of thumb, poisoning of invertebrates in South African streams is probable when less than 50 animals per square foot (about 0.1 square meter) are present in stones-incurrent biotopes (sampling with a square foot sampler (SuRBER, 1936) fitted with bolting silk with 23 meshes $\mathrm{cm}^{-1}$ and $0.29 \mathrm{~mm}$ between the threads). However, severe floods accompanied by scouring of river beds also result in sparse faunas with less than 50 individuals per square foot. Since many of the taxa most closely associated with stream pollution are particularly susceptible to being carried away by floods, the Biotic Index is not reliable in recently flooded rivers.

\section{GUIDING PRINCIPLES}

Among the important findings of faunal surveys of rivers is the fact that water courses are made up of several well defined biotopes such as stones-in-current, stones-out-of-current, fringing vegetation, fully aquatic vegetation and several types of sediment. Each of these biotopes has, in a natural water course, a characteristic fauna and may therefore be treated as a separate entity. Indeed, as several of the most obvious faunal changes associated with organic pollution consist of the appearance of taxa in biotopes where they are not normally found, the various biotopes must be treated separately in any attempt to relate fauna to water quality.

A Biotic Index should be based, initially at least, on as broad a foundation as possible. It should use data from field collections or samples of the fauna, collected from the various biotopes separately. All the animals in such samples and their abundance relative to one another should be taken into account. Contrarywise it is desirable to minimize the time expended on the analysis of biological samples.

The Biotic Index should not make rigorous demands on field sampling techniques. Sample size should be reasonably flexible, though it is necessary to define sampling apparatus and mesh size of netting. Data used in this paper resulted from collecting animals with a circular hand net or a square foot sampler (SURBER, 1936). The netting attached to this equipment was bolting silk with 23 meshes $\mathrm{cm}^{-1}$ and $0.29 \mathrm{~mm}$ between the threads.

Possible Biotic Index values should be limited and fall into a linear scale of stream quality.

\section{THE BIOTIC INDEX}

The Biotic Index developed here applies only to collections of animals from the stones-in-current biotope. It was decided that Biotic Index values should lie between 0 (clean water) and 10 (highly polluted water) and that every animal in each sample, except the Cladocera and Copepoda, should contribute to it. (Most Cladocera and Copepoda in stones-in-current samples drift into the sampling apparatus and the numbers of them collected are therefore greatly influenced by the current speed and the time taken in sampling).

Taxa recorded from stones-in-current biotopes in the South African literature given in the Introduction were listed. The literature was then used to allocate each taxon a Quality Value between 0 and 10, depending on the type of water in which it occurred in greatest numbers in the stones-in-current biotopes. Clean water species were valued at 0 and highly polluted water species at 10 , with species showing peak numbers in intermediate waters being allocated intermediate values. At this stage it was thought 
that a Biotic Index might easily be arrived at from the taxa present, the numbers of individuals of each taxon and the Quality Value. Each individual animal would be recorded at its Quality Value on the scale 0-10, the Quality Values would be summed for the sample and then divided by the number of individuals in the sample. The resulting figure, which would lie between 0 and 10 would be a mean Quality Value for all the animals in the sample and would be the Biotic Index Value.

It soon became apparent that several common taxa were found in large numbers in a variety of water qualities. These taxa were Nais, Oligochaeta-other-than Nais, Cypridopsis (Ostracoda), Chironomini (excluding Chironomus), Orthocladiinae and Simuliidae. Useful Quality Values for these tolerant taxa were only arrived at when they were made to vary following the occurrence of a broadly-speaking clean water group of animals, the Baetid Ephemeroptera. Where Baetid Ephemeroptera were diverse and abundant, large numbers of individuals of tolerant taxa did not indicate water pollution, and their Quality Values were arranged to show this. As the numbers and diversity of the Baetid Ephemeroptera decreased, so the Quality Values for tolerant taxa were made to increase. However, a common Baetid, Baetis harrisoni Barnard, was itself tolerant of some deterioration in water quality. A sliding scale of Quality Values was arrived at for $B$. harrisoni too, this time dependent on the diversity of the Ephemeroptera as a whole.

Biotic Index Values were then calculated for numerous faunal samples, original data from South African river surveys being used. Quality Values for important taxa were adjusted by trial and error until they resulted in Biotic Index Values which broadly followed the recorded chemical quality of the water, allowing for the fact that snap water samples for chemical analysis are not always representative. Quality Values used in the calculation of the Biotic Index Values which follow are shown in TABLE 1, while worked examples based on field samples are shown in TABLES 2-4.

Here the significance of taxa whose Quality Value is 0 becomes apparent, for in the final division to arrive at the Biotic Index Value, they contribute nothing to the enumerator, but may influence the denominator considerably (see TABLE 2 in particular). Readers from the Northern Hemisphere may be perplexed by the absence of Plecoptera from these tables and the importance of the Baetid Ephemeroptera. In Africa the Plecoptera are poorly represented and are to some extent replaced by the Baetid Ephemeroptera of which there are many species.

\section{Application of the Biotic Index and comparison with another index}

OLIFF (1963) measured the 5-day Biochemical Oxygen Demand (B.O.D.) of the water and simultaneously collected the stones-in-current fauna in May and in August, 1959 at a large number of places in the Buffalo River in Natal. In both these months the river flow was low and stable. Organic pollution of the river was due to a single source, a sewage works effluent in the upper reaches of the river course. Field conditions were therefore such that a close relationship between the chemistry of the river and the fauna would be expected. B.O.D. values ranged up to $8 \cdot 3 \mathrm{ppm} \mathrm{O}_{2}$. Biotic Index Values were calculated from Oliff's tabulated faunal data which he did not publish, but which formed the basis of his published FIG. 12 (OLIFF, 1953). The correlation coefficient between B.O.D. and Biotic Index Value in May, 1959 was 0.66 (22 samples collected), while in August, 1959 the correlation coefficient was 0.51 (12 samples). Both these coefficients are significant at the 5 per cent level. 
Table 1. Quality Values for the calculation of the Biotic Index value

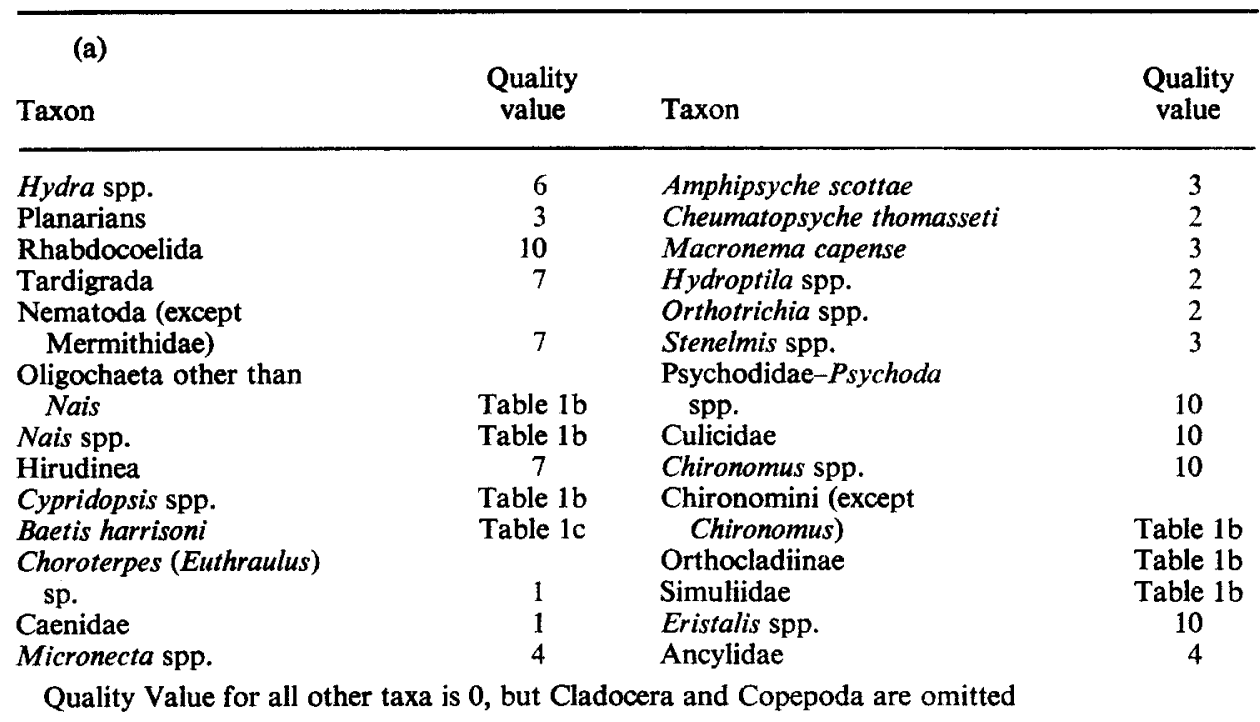

(b)

Quality values (dependent on Baetid Ephemeroptera shown on the left)

\begin{tabular}{cccccc}
\multicolumn{2}{c}{ Baetid Ephemeroptera } & & & \multicolumn{1}{c}{$\begin{array}{c}\text { Cypridopsis, } \\
\text { Chironomini } \\
\text { (except }\end{array}$} \\
$\begin{array}{c}\text { Number } \\
\text { of } \\
\text { species }\end{array}$ & $\begin{array}{c}\text { Individuals } \\
\text { as \% of } \\
\text { whole fauna* }\end{array}$ & $\begin{array}{c}\text { Oligochaeta } \\
\text { other than } \\
\text { Nais }\end{array}$ & Nais & $\begin{array}{c}\text { Chironomus), } \\
\text { Orthocladiinae }\end{array}$ & Simuliidae \\
\hline 5 or more & any & 8 & 1 & 1 & 0 \\
3 or 4 & $>20$ & 8 & 1 & 1 & 0 \\
& $10-20$ & 8 & 3 & 3 & 3 \\
& $5-10$ & 8 & 5 & 3 & 3 \\
1 or 2 & $<5$ & 8 & 5 & 5 & 1 \\
& $>20$ & 8 & 1 & 1 & 3 \\
& $10-20$ & 8 & 3 & 3 & 5 \\
absent & $5-10$ & 8 & 5 & 5 & 5 \\
\hline
\end{tabular}

(c)

To arrive at Baetid per cent for (b) multiply

Ephemeroptera

B. harrisoni

B. harrisoni numbers

Quality value by

$B$. harrisoni only

$B$. harrisoni and 1 other species

$B$. harrisoni and 2 other species

$B$. harrisoni and 3 or more species

$\begin{array}{ll}6 & 0.5 \\ 4 & 0.5 \\ 2 & 0.5 \\ 0 & 1.0\end{array}$

* 1. Fauna is all animals in sample except Cladocera and Copepoda

2. The percentage is calculated after multiplying the Baetis harrisoni numbers by either 0.5 or 1 as shown in T ABLE 1C. 
Table 2. Example of calculation of Biotic Index. A clean stream, THe Klein VaAl RIver, Southern Transvaal. Stones-in-CurRent, June 1960

\begin{tabular}{|c|c|c|c|}
\hline Taxon & $\begin{array}{l}\text { Number of } \\
\text { individuals }(a)\end{array}$ & $\begin{array}{c}\text { Quality } \\
\text { value }(b)^{*}\end{array}$ & $a \times b$ \\
\hline Planarians & 82 & 3 & 246 \\
\hline Nematoda-Mermithidae & 32 & 0 & 0 \\
\hline Nematoda-other & 9 & 7 & 63 \\
\hline \multicolumn{4}{|l|}{ Oligochaeta } \\
\hline Nais spp. & 9 & $1^{*}$ & 9 \\
\hline Limnodrilus spp. & 1 & $8^{*}$ & 8 \\
\hline \multicolumn{4}{|l|}{ Hydracarina } \\
\hline Hydrachnellae & 32 & 0 & 0 \\
\hline \multicolumn{4}{|l|}{ Plecoptera } \\
\hline Neoperla spio & 1 & 0 & $\mathbf{0}$ \\
\hline \multicolumn{4}{|l|}{ Ephemeroptera Baetidae } \\
\hline Baetis harrisoni & 1068 & $0^{*}$ & 0 \\
\hline Baetis latus & 2 & 0 & 0 \\
\hline Centroptilum pulchrum & 18 & 0 & 0 \\
\hline Centroptilum sudafricanum & 440 & 0 & 0 \\
\hline Centroptilum sp. I & 37 & 0 & 0 \\
\hline Pseudocloeon maculosum & 14 & 0 & 0 \\
\hline \multicolumn{4}{|l|}{ Ephemeroptera, other families } \\
\hline Adenophlebia sp. & 1 & 0 & 0 \\
\hline Afronurus sp. & 9 & 0 & 0 \\
\hline Choroterpes (Euthraulus) sp. & 262 & 1 & 262 \\
\hline Caenidae & 235 & 1 & 235 \\
\hline Neurocaenis sp. & 150 & 0 & 0 \\
\hline \multicolumn{4}{|l|}{ Odonata } \\
\hline Aeshna sp. & 1 & 0 & 0 \\
\hline \multicolumn{4}{|l|}{ Hemiptera } \\
\hline Micronecta sp. & 1 & 4 & 4 \\
\hline \multicolumn{4}{|l|}{ Trichoptera } \\
\hline Cheumatopsyche afra & 37 & 0 & 0 \\
\hline Hydroptila capensis & 2 & 2 & 4 \\
\hline Ecnomus sp. & 1 & 0 & 0 \\
\hline \multicolumn{4}{|l|}{ Coleoptera } \\
\hline Aulonogyrus sp. & 14 & 0 & 0 \\
\hline Hydraenidae & 41 & $\mathbf{0}$ & 0 \\
\hline Stenelmis sp. & 2 & 3 & 6 \\
\hline other Elmidae & 52 & 0 & $\mathbf{0}$ \\
\hline \multicolumn{4}{|l|}{ Diptera } \\
\hline Tipulid & 1 & 0 & 0 \\
\hline Simuliidae & 283 & $0^{*}$ & 0 \\
\hline Chironomini & 11 & $1^{*}$ & 11 \\
\hline Tanytarsini & 9 & 0 & 0 \\
\hline \multirow{3}{*}{$\begin{array}{l}\text { Corynoneura sp. } \\
\text { Orthocladiinae }\end{array}$} & 40 & 0 & 0 \\
\hline & 46 & $1^{*}$ & 46 \\
\hline & Total 2937 & Total & 894 \\
\hline
\end{tabular}

- 6 Baetid species present (and 11 Ephemeroptera species for B. harrisoni value).

Biotic Index Value $=\frac{\Sigma(a \times b)}{\text { Number of individuals }}=\frac{894}{2937}=0.3$. 
Table 3. Example of calculation of Biotic Index. Stones-in-current in a POlluted Part of the VaAl River, Southern Transvaal. July 1959

\begin{tabular}{|c|c|c|c|}
\hline Taxon & $\begin{array}{l}\text { Number of } \\
\text { individuals }(a)\end{array}$ & $\begin{array}{c}\text { Quality } \\
\text { value }(b)^{*}\end{array}$ & $a \times b$ \\
\hline Planarians & 64 & 3 & 192 \\
\hline Nematoda & 615 & 7 & 4305 \\
\hline \multicolumn{4}{|l|}{ Oligochaeta } \\
\hline Limnodrilus spp. & 167 & $8^{*}$ & 1336 \\
\hline Tubifex sp. & 7 & $8^{*}$ & 56 \\
\hline Branchiura sp. & 3 & $8^{*}$ & 24 \\
\hline Nais sp. & 29,573 & $8^{*}$ & 236,584 \\
\hline Pristina sp. & 625 & $8^{*}$ & 5000 \\
\hline \multicolumn{4}{|l|}{ Ephemeroptera Baetidae } \\
\hline Baetis harrisoni & 22 & $0^{*}$ & 0 \\
\hline Centroptilum excisum & 3 & 0 & 0 \\
\hline \multicolumn{4}{|l|}{ Ephemeroptera, other families } \\
\hline Caenidae & 5 & 1 & 5 \\
\hline Choroterpes (Euthraulus) sp. & 44 & 1 & 44 \\
\hline \multicolumn{4}{|l|}{ Odonata } \\
\hline Paragomphus sp. & 1 & 0 & 0 \\
\hline \multicolumn{4}{|l|}{ Trichoptera } \\
\hline Amphipsyche scottae & 36 & 3 & 108 \\
\hline Cheumatopsyche thomasseti & 29 & 2 & 58 \\
\hline Cheumatopsyche afra & 1 & $\overline{0}$ & 0 \\
\hline Macronema sp. & 47 & 3 & 141 \\
\hline Ecnomus sp. & 2 & 0 & 0 \\
\hline Hydroptila sp. & 3 & 2 & 6 \\
\hline \multicolumn{4}{|l|}{ Coleoptera } \\
\hline Aulonogyrus sp. & 6 & 0 & 0 \\
\hline Stenelmis sp. & 305 & 3 & 915 \\
\hline other Elmidae & 6 & 0 & 0 \\
\hline Hydraenidae & 1 & 0 & 0 \\
\hline \multicolumn{4}{|l|}{ Diptera } \\
\hline Simuliidae & 4 & $5^{*}$ & 20 \\
\hline Chironomini & 966 & $7^{*}$ & 6972 \\
\hline Pentaneura sp. & 34 & 0 & 0 \\
\hline Orthocladiinae & 2,075 & $7 *$ & 14,525 \\
\hline Ceratopogonidae & 2 & 0 & 0 \\
\hline \multicolumn{4}{|l|}{ Mollusca } \\
\hline Burnupia sp. (Ancylid) & 12 & 4 & 48 \\
\hline \multirow[t]{2}{*}{ Pisidium sp. } & 5 & 0 & 0 \\
\hline & 34,663 & Total & 270,341 \\
\hline
\end{tabular}

* 2 Baetid species, < 5 per cent, for B. harrisoni 3 other Ephemeroptera.

Biotic Index Value $=\frac{270341}{34663}=7 \cdot 8$.

Chemical conditions in the Jukskei River, studied by Allanson (1961), were highly variable but the quality of the water improved from the polluted headwaters (Station 2) downstream to Station 22. This was shown by the Biotic Index Values for the stonesin-current fauna (FIG. 1).

Several diversity indices were compared as biological indices of water quality by WILHM (1967). While the relationship $S / \sqrt{ } N$ (where $S$ is the total number of species, $N$ is the total number of individuals in a sample) was not favoured by Wilhm as much as 
Table 4. Example of calculation of Biotic Index. Stones-In-current in A HIGHLY POLLUTED PART OF THE JUKSKeI RIVER, AUguST 1957

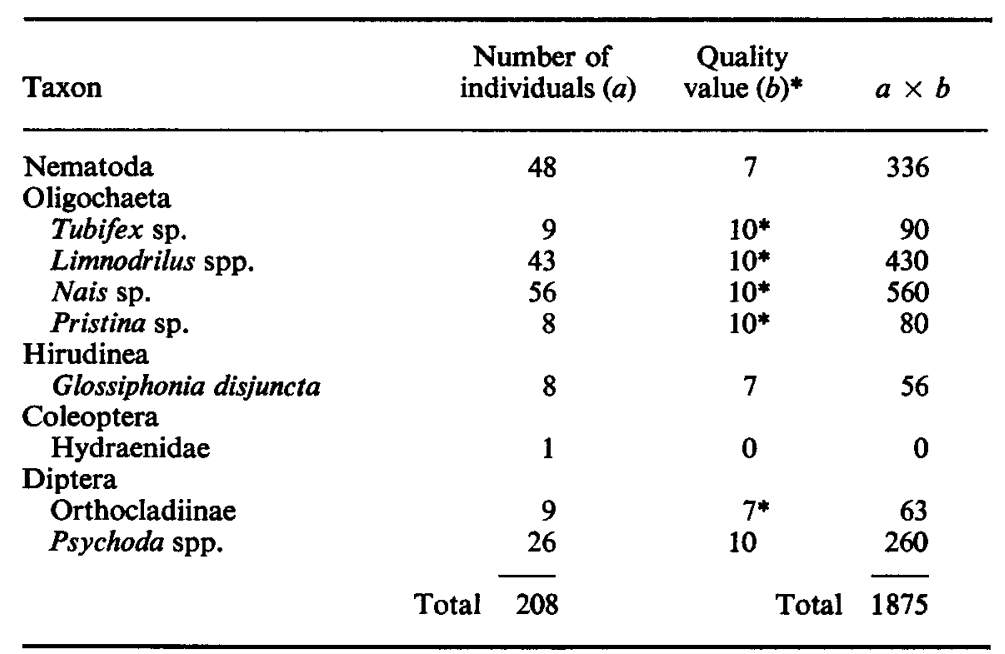

* No Baetidae.

Biotic Index Value $=\frac{1875}{208}=9 \cdot 0$.

some other relationships, scrutiny of his chemical data showed that $S / \sqrt{ } N$ values followed changes in stream quality rather better than values for the other relationships. Correlation coefficients between B.O.D. and $S / \sqrt{ } N$ for the Buffalo River data described above were -0.60 and -0.39 and were therefore not as close as they were between B.O.D. and Biotic Index Values. $S / \sqrt{ } N$ values for the Jukskei River stones-in-current

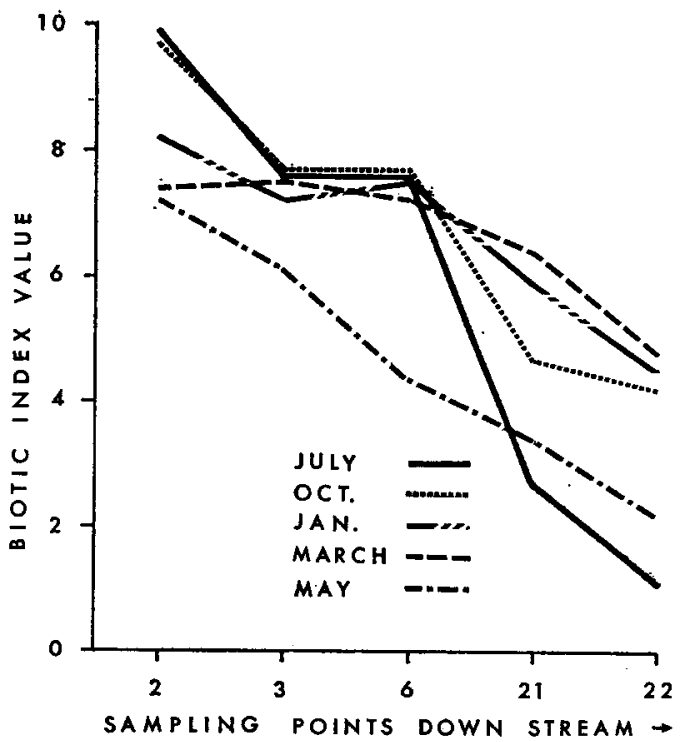

FIG. 1. Changes in Biotic Index Values along the Jukskei River. Sampling points numbered following AlLanson (1961). 


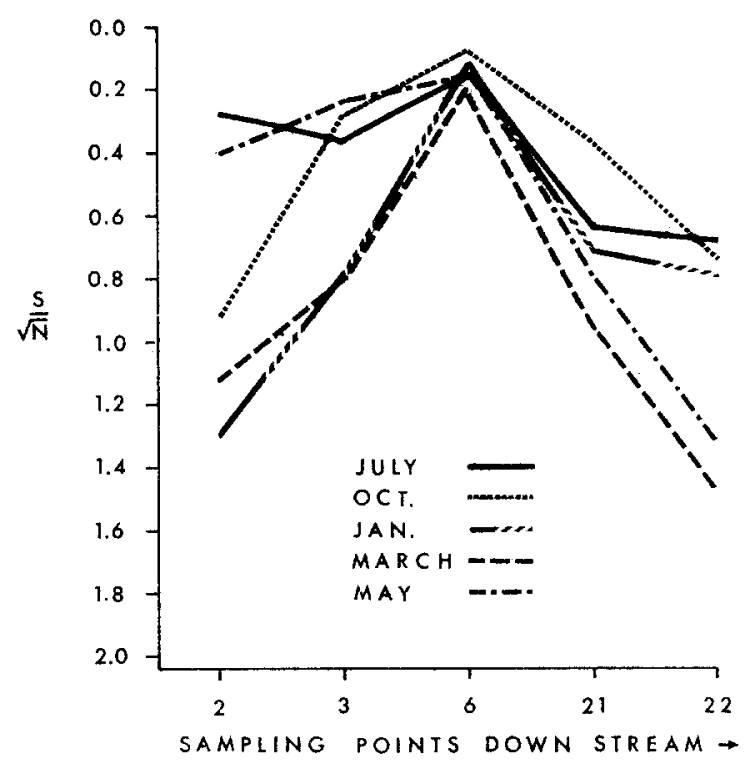

FIG. 2. Changes in $S / \sqrt{ } N$ along the Jukskei River. $S$ is number of species, $N$ is number of individuals belonging to those species. Sampling points numbered following ALLANSON (1961).

communities (FIG. 2) indicate that the water quality was worst at Station 6. This was not so. It may therefore be inferred that the Biotic Index described here gives a better measure of quality in South African flowing waters than do at least some of the more promising relationships between $S$ and $N$.

\section{DISCUSSION}

From a large number of calculations of Biotic Index Values for South African river survey data, the following interpretation of Index Values is offered:

Value

Interpretation

0-2 Clean unpolluted waters.

2-4 Slightly enriched waters, the slight enrichment may be due either to the natural occurrence of organic matter or to high quality effluents containing a little organic matter or its breakdown products. Chemical changes in the water may be hardly detectable.

4-7 Enriched waters, the higher Biotic Index Value, the greater the enrichment. Obvious increases in the B.O.D. and nitrogenous compounds in the water and rather wide diurnal fluctuations in the dissolved oxygen are to be expected.

7-10 Polluted waters in which there will be great increases in the chemical parameters associated with organic pollution.

The Biotic Index presented here requires a detailed analysis of the fauna collected. However, it does not call for identifications to be carried as far as they were in the 
detailed river surveys which provided the raw data for this paper (see Introduction). For instance it is necessary to divide the aquatic worms only into Nais and Oligochaeta-other-than Nais, the Simuliidae are treated as a single group and the Cladocera and Copepoda are ignored. Approaches which hold promise in the reduction of time and effort to arrive at a Biotic Index Value include the determination of the minimum sample size compatible with accuracy and also the determination of the optimum size of net mesh for sampling apparatus.

The Biotic Index has been arrived at by the assignment of Quality Values to the various taxa on an empirical basis. There is however a reasonably close relationship between the known biology of the taxa and their Quality Values. Thus taxa wellknown for their ability to live in poorly oxygenated waters through specialization of their respiratory processes (Culicidae, Psychoda spp., Chironomus spp., Eristalis spp.) have Quality Values associated with highly polluted waters (TABLE 1). Detritus feeders (Oligochaeta) have large Quality Values, and are associated with organic matter often found in polluted waters. In intermediate waters where there are increases in the amounts of algae and of filterable organic particles, living (Protozoa, Entomostraca) or dead, there are increases in the algal feeders and the filter feeders. This is reflected in the intermediate Quality Values of algal feeders such as Hydroptila spp., Stenelmis spp. and Ancylidae and of filter feeders such as the Hydropsychid Trichoptera and the Simuliidae.

The use of a sliding scale of Quality Values for certain taxa (TABLE 1b) calls for comment. These are all taxa in which it is not easy or sometimes impossible to identify individuals to species in the aquatic stage. Each of these taxa probably includes some species intolerant of organic pollution and others found mainly in polluted waters. Were it possible to assign each individual to a species in these taxa, it might therefore be possible to do away with the sliding scales in TABLE $1 \mathrm{~b}$ and to include the taxa broken down to species in TABLE 1a. However in terms of the time expended in sorting samples to arrive at a Biotic Index Value this refinement of taxonomic penetration would be of dubious value.

It is of course desirable that Biotic Indices should be worked out for all the principal biotopes in streams and rivers. However preliminary looking over of the South African data for these other biotopes indicates that this will not be easy, mainly because their faunal communities are rather variable even in clean streams and rivers.

\section{REFERENCES}

Allanson B. R. (1961) Investigations into the ecology of polluted inland waters in the Transvaal. Part 1. The physical, chemical and biological conditions in the Jukskei-Crocodile River system. Hydrobiologia 18, 1-76.

BEAK T. W. (1965) A biotic index of polluted streams and its relationship to fisheries. Advances in Water Pollution Research, Proc. of the Second Int. Conf., Tokyo. 1, 191-210.

Butcher R. W. (1946) The biological detection of pollution. J. Inst. Sew. Purif. 2, 92-97.

Cairns J., Albaugh D. W., Bussey F. and Chanay M. D. (1968) The sequential comparison indexa simplified method for non-biologists to estimate relative differences in biological diversity in stream pollution studies. J. Wat. Pollut. Control Fed. 40, 1607-1613.

Chutter F. M. (1963) Hydrobiological studies on the Vaal River in the Vereeniging area. Part 1. Introduction, water chemistry and biological studies on the fauna of habitats other than muddy bottom sediments. Hydrobiologia 21, 1-65.

ChutTer F. M. (1968) On the ecology of the fauna of stones in the current in a South African river supporting a very large Simulium (Diptera) population. J. appl. Ecol. 5, 531-561.

Chutter F. M. (1970) Hydrobiological studies in the catchment of Vaal Dam, South Africa. Part 1. River zonation and the benthic fauna. Int. Rev. ges. Hydrobiol. 55, 445-494. 
ChUtTER F. M. (1971) Hydrobiological studies in the catchment of Vaal Dam, South Africa. Part 2. The effects of stream contamination on the fauna of stones-in-current and marginal vegetation biotopes. Int. Rev. ges. Hydrobiol. 56, 227-240.

Harrison A. D. (1958a) Hydrobiological studies on the Great Berg River, Western Cape Province. Part 2. Quantitative studies on sandy bottoms, notes on tributaries and further information on the fauna, arranged systematically. Trans. R. Soc. S. Afr. 35, 227-276.

Harrison A. D. (1958b) Hydrobiological studies on the Great Berg River, Western Cape Province. Part 4. The effects of organic pollution on the fauna of parts of the Great Berg River System and of the Krom Stream, Stellenbosch. Trans. R. Soc. S. Afr. 35, 299-329.

HARRISON A. D. (1961) The role of river fauna in the assessment of pollution. In: Proceedings of a Specialist Meeting on Water Treatment in Pretoria 1960. Commission for technical co-operation in Africa south of the Sahara, Scientific Council for Africa south of the Sahara, Publ. No. 64, 199-212.

Harrison A. D. and Elsworth, J. F. (1958) Hydrobiological studies on the Great Berg River, Western Cape Province. Part 1. General description, chemical studies and main features of the flora and fauna. Trans. R. Soc. S. Afr. 35, 125-226.

Hawkes H. A. (1962) Biological aspects of river pollution. In: KLeIN, L., River Pollution II Causes and Effects. Butterworths, London.

Hynes H. B. N. (1960) The Biology of Polluted Waters. Liverpool University Press, Liverpool.

HyNEs H. B. N. (1964) The use of biology in the study of water pollution. Chem. Ind. $435-436$.

Kolkwitz R. (1950) Oekologie der Saprobien. Uber die Beziehungen der Wasserorganismen zur Umwelt. Schr Reiche Ver. Wasserhyg. 4, 64.

Kolkwitz R. and Marsson, M. (1908) Okologie der pflanzlichen Saprobien. Ber. dt. bot. Ges. 26, 505-519.

Kolkwirz R. and Marsson M. (1909) Ökologie der tierische Saprobien. Beiträge zur Lehre von der biologische Gewässerbeurteilung. Int. Rev. Hydrobiol. 2, 126-152.

LIEBMANN H. (1951) Handbuch der Frischwasser und Abwasserbiologie. Oldenbourg, Munchen.

MAthis B. J. and DoRRIS T. C. (1968) Community structure of benthic macro-invertebrates in an intermittent stream receiving oil field brines. Am. Midl. Nat. 80, 428-439.

OLIFF W. D. (1960a) Hydrobiological studies on the Tugela River system. Part 1. The main Tugela River. Hydrobiologia 14, 281-385.

OufF W. D. (1960b) Hydrobiological studies on the Tugela River system. Part 2. Organic pollution in the Bushmans River. Hydrobiologia 16, 137-196.

OlifF W. D. (1963) Hydrobiological studies on the Tugela River system. Part 3. The Buffalo River. Hydrobiologia 21, 355-379.

PATRICK R. (1950) Biological measure of stream conditions. Sewage ind. Wastes 25, 210-214.

PATRICK R. (1951) A proposed biological measure of stream conditions. Verh. int. Verein. theor. angew. Limnol. 11, 299-307.

Patten B. C. (1962) Species diversity in net phytoplankton of Raritan Bay. J. mar. Res. 20, 57-75.

Prelou E. C. (1966) The measurement of diversity in different types of biological collections. J. theor. Biol. 13, 131-144.

SURBER E. W. (1936) Rainbow trout and bottom fauna production in one mile of stream. Trans. Am. Fish. Soc. 66, 193-202.

WILHM J. L. (1967) Comparison of some diversity indices applied to populations of benthic macroinvertebrates in a stream receiving organic wastes. $J$. Wat. Pollut. Control Fed. 39, 1673-1683.

Wilhm J. L. (1970) Community diversity. In The Stream Ecosystem, pp. 8-13. An American Association for the Advancement of Science Symposium. Institute of Water Research, Michigan State University, Technical Report No. 7.

WILHM J. L. and DoRRIS, T. C. (1966) Species diversity and benthic macroinvertebrates in a stream receiving domestic and oil refinery effluents. Am. Midl. Nat. 76, 427-449.

Woodiwiss F. S. (1964) The biological system of stream classification used by the Trent River Board. Chemy Ind. 443-447.

Wurtz C. B. (1955) Stream biota and stream pollution. Sewage ind. Wastes 27, 1270-1278. 